\title{
EFEKTIVITAS METODE COOPERATIVE LEARNING TIPE INSIDE-OUTSIDE CIRCLEDALAM MENINGKATKAN KEMAMPUAN BERBICARA BAHASA JEPANG (PENELITIAN EKSPERIMEN KUASI TERHADAP SISWA KELAS XII IPA 2 SMA PASUNDAN 2 BANDUNG)
}

\author{
Dhiar Rachma Diyanthi, Melia Dewi Judiasri', Dianni Risda ${ }^{2}$ \\ Departemen Pendidikan Bahasa Jepang, Fakultas Pendidikan Bahasa dan Sastra, Universitas \\ Pendidikan Indonesia \\ dhiarrachma@gmail.com
}

\begin{abstract}
Abstrak
Penelitian ini dilatar belakangi oleh kurangnya kesempatan siswa untuk berbicara saat pembelajaran bahasa Jepang. Setengah dari sampel menyatakan bahwa selama ini kurang mendapatkan kesempatan berbicara bahasa Jepang dalam pembelajaran bahasa Jepang. Padahal saat ini siswa dituntut untuk dapat berbicara dan berkomunikasi secara global. Dan kemampuan berbicara adalah implementasi dari materi-materi pelajaran bahasa Jepang yang telah dipelajari. Untuk mengatasi masalah tersebut, peneliti mengujicobakan metode cooperative learning tipe inside-outside circle dalam pembelajaran bahasa Jepang terhadap siswa XII IPA 2 SMA Pasundan 2 Bandung. Tujuan dari dilaksanakannya pembelajaran dengan metode ini adalah agar siswa mampu untuk berbicara dengan bahasa Jepang secara aktif dan menguji efektivitas dari metode tersebut.Penelitian ini menggunakan metode eksperimen kuasi (pre-test and post-test one group). Teknik pengambilan sampling dengan cara random sampling. Populasi dalam penelitian ini adalah seluruh siswa SMA Pasundan 2 Bandung dan sampelnya adalah 16 orang siswa kelas XII IPA 2 sebagai kelas eksperimen. Instrumen dalam penelitian ini adalah tes dan angket.Dari hasil analisa data tes diperoleh nilai t-hitung sebesar 4,205. Dan dengan db 15 pada tahap signifikansi 5\% diperoleh t-tabel sebesar 2,13 dan signifikansi $1 \%$ diperoleh t-tabel sebesar 2,95. Karena nilai t-hitung > t-tabel , maka Hk diterima. Hal tersebut berarti terdapat perbedaan yang signifikan pada kemampuan berbicara siswa sebelum dan sesudah diterapkannya metode cooperative learning tipe inside-outside circle. Hal tersebut diperkuat dengan hasil angket yang menyatakan bahwa lebih dari setengah responden merasakan pengaruh penerapan metode cooperative learning tipe inside-outside circle terhadap kemampuan berbicara bahasa Jepang.
\end{abstract}

Keyword: kemampuan berbicara, metode cooperative learning tipe inside-outside circle

1. Dra. Hj. Melia Dewi J, M.Hum., M.Pd. Penulis Penanggung Jawab 1

2. Hj. Dianni Risda, M. Ed. Penulis Penanggung Jawab 2 


\title{
THE EFFECTIVITY OF COOPERATIVE LEARNING METHOD TYPE OF INSIDE-OUTSIDE CIRCLE FOR IMPROVING JAPANESE SPEAKING ABILITY (QUASI EXPERIMENT RESEARCH TO STUDENTS OF XII IPA 2 SMA PASUNDAN 2 BANDUNG)
}

\author{
Dhiar Rachma Diyanthi, Melia Dewi Judiasri', Dianni Risda ${ }^{2}$ \\ Departemen Pendidikan Bahasa Jepang, Fakultas Pendidikan Bahasa dan Sastra, Universitas \\ Pendidikan Indonesia \\ dhiarrachma@gmail.com
}

\begin{abstract}
This research was motivated by the lack of opportunity to speak Japanese during the class. $50 \%$ of the sample stated that they are have a small opportunity to speak Japanese during learning Japanese. Yet, in this time students are required to be able to talk and communicate globally. And the ability to speak is the implementation of Japanese language lessons. To overcome these problems, researcher tested the method of cooperative learning type of inside-outside circle in learning the Japanese language to students XII IPA 2 SMA Pasundan 2 Bandung. The purpose of the implementation of learning with this method is the students are able to speak japanese actively and to test the effectiveness of the method. This research uses a quasi experimental (pre-test and post-test one group). Sampling technique by means of random sampling. The population in this study were all high school students of SMA Pasundan 2 Bandung and the sample was 16 students of class XII IPA 2 as the experimental class. Instruments for this research is a test and questionnaire. From the analysis of obtained data, value t-count of 4,205. And with $15 \mathrm{db}$ at this stage of the 5\% significance was obtained t-table by 2.13 and $1 \%$ significance obtained t-table by 2.95 . Because the value of $\mathrm{t}$ count $>\mathrm{t}$-table, then $\mathrm{Hk}$ accepted. This means that there are significant differences in their speaking ability before and after the implementation of cooperative learning type of inside-outside circle. This is reinforced by the results of a questionnaire which states that more than half of the respondents feel the effect of the application of cooperative learning type of inside-outside circle of the ability to speak Japanese.
\end{abstract}

Keyword: speaking ability, cooperative learning method type of inside-outside circle

1. $\quad$ Dra. Hj. Melia Dewi J, M.Hum., M.Pd. Penulis Penanggung Jawab 1

2. Hj. Dianni Risda, M. Ed. Penulis Penanggung Jawab 2 


\section{PENDAHULUAN}

Dalam Nihongo Kyouiku Jiten pengertian berbicara adalah 話すということ は人と人の間で意思を伝えるあう、いわゆるコミュニケーションであり、 その形には 1 人たい 1 人、 1 人対多数、多数対 1 人などがある (Ogawa, 1984, hlm. 636). "Berbicara merupakan suatu komunikasi, yaitu antara manusia dan manusia yang saling menyampaikan maksudnya satu sama lain, yang bentuknya bisa antara satu orang ke satu orang lainnya, satu orang kepada orang banyak, ataupun sebaliknya." (Ogawa, 1984, hlm. 636).

Kemampuan berbicara adalah implementasi dari pengetahuan siswa terhadap kosakata bahasa Jepang dan pola kalimat yang telah dipelajari. Kurangnya pemahaman siswa terhadap pembelajaran bahasa Jepang dan minat siswa dalam bahasa Jepang, menuntut guru untuk lebih kreatif dan inovatif dalam kegiatan belajar mengajar. Salah satunya adalah dengan menggunakan metode yang berbeda dari metode pembelajaran pada umumnya. Dengan metode tersebut, diharapkan dapat meningkatkan pemahaman dan minat siswa dalam pembelajaran bahasa Jepang.

Untuk meningkatkan minat siswa dan menuntut siswa untuk belajar aktif, peneliti memilih metode cooperative learning tipe inside-outside circle untuk pembelajaran bahasa Jepang dalam kemampuan berbicara bahasa Jepang. Kemampuan berbicara bahasa Jepang yang dimaksud dalam penelitian ini adalah siswa mampu untuk menjawab pertanyaan-pertanyaan yang diberikan oleh peneliti dan siswa mampu untuk mengungkapkan suatu situasi dan menanyakan kepada lawan bicara sesuai dengan topik yang diberikan oleh peneliti. Metode cooperative learning atau pembelajaran kooperatif adalah strategi belajar dengan sejumlah siswa sebagai anggota kelompok kecil yang tingkat kemampuannya berbeda (Isjoni, 2011, hlm. 12). Pada model pembelajaran kooperatif tipe inside-outside circle atau lingkaran dalam-lingkaran luar, siswa membentuk dua lingkaran konsentris atau dua barisan di mana siswa saling berhadapan satu sama lain (Lie, 2002, hlm. 64). Dalam penelitian ini, siswa akan dibagi menjadi dua lingkaran. Ada yang menjadi lingkaran dalam dan ada yang menjadi lingkaran luar dengan jumlah yang sama banyak. Siswa yang menjadi lingkaran dalam harus menghadap keluar sehingga berhadap-hadapan dengan siswa lingkaran luar. Metode ini diharapkan dapat meningkatkan cara belajar siswa menuju belajar yang lebih baik, sikap tolong-menolong dalam beberapa perilaku sosial, meningkatkan minat dan motivasi siswa dalam pembelajaran bahasa Jepang terutama dalam pembelajaran berbicara bahasa Jepang.

Berdasarkan uraian di atas, peneliti tertarik untuk meneliti bagaimana pengaruh metode cooperative learning tipe inside-outside circle terhadap kemampuan siswa dalam berbicara bahasa Jepang. Dengan demikian, peneliti mengangkat penelitian yang berjudul "Efektivitas Metode Cooperative Learning Tipe Inside-Outside Circle dalam Meningkatkan Kemampuan Berbicara Bahasa Jepang (Penelitian Eksperimen Kuasi Terhadap Siswa Kelas XII IPA 2 SMA Pasundan 2 Bandung)”.

Tujuan dilakukannya penelitian ini adalah untuk mengetahui kemampuan berbicara bahasa Jepang siswa sebelum menggunakan metode cooperative learning tipe inside-outside circle dalam pembelajaran bahasa Jepang, untuk mengetahui kemampuan berbicara bahasa Jepang siswa setelah menggunakan metode cooperative learning tipe inside-outside circle dalam pembelajaran bahasa Jepang, untuk mengetahui efektivitas metode cooperative learning tipe inside-outside circle pada kemampuan siswa dalam berbicara dengan bahasa Jepang, dan untuk mengetahui tanggapan siswa terhadap pembelajaran bahasa Jepang dengan 
menggunakan metode cooperative learning tipe inside-outside circle terutama dalam meningkatkan kemampuan berbicara bahasa Jepang.

Adapun teori dasar yang berkaitan dengan penelitian ini adalah sebagai berikut:

1. Berbicara merupakan suatu komunikasi, yaitu antara manusia dan manusia yang saling menyampaikan maksudnya satu sama lain, yang bentuknya bisa antara satu orang ke satu orang lainnya, satu orang kepada orang banyak, ataupun sebaliknya (Ogawa, 1984, hlm. 636). Sedangkan menurut silabus bahasa Jepang SMA sesuai dengan kurikulum KTSP, kemampuan berbicara adalah siswa mampu untuk mengungkapkan informasi secara lisan dalam bentuk paparan atau dialog sederhana bahasa Jepang. Serta, mampu menyampaikan berbagai informasi secara lisan dengan tepat dalam kalimat sederhana sesuai konteks.

2. Pembelajaran cooperative learning tidak sama dengan sekedar belajar dalam kelompok. Ada unsur-unsur dasar pembelajaran kooperatif yang membedakannya dengan pembagian kelompok yang dilakukan asal-asalan. Pelaksanaan prosedur model cooperative learning dengan benar akan memungkinkan pendidik mengelola kelas dengan lebih efektif (Lie, 2002, hlm. 28).

3. Metode inside-outside circle dikembangkan oleh Spencer Kagan (1994). Pada metode pembelajaran kooperatif tipe inside-outside circle ini, siswa membentuk dua lingkaran konsentris atau dua barisan di mana siswa saling berhadapan satu sama lain. Pertama-tama siswa membentuk kelompok kecil yang berisi empat orang untuk mendiskusikan topik pembicaraan yang diberikan oleh peneliti. Setelah berdiskusi, seluruh siswa membaur dan membentuk dua buah lingkaran besar yaitu lingkaran dalam dan luar dimana nantinya siswa dari lingkaran dalam dan luar akan saling berhadap-hadapan dan akan saling berbicara sesuai dengan topik yang didapatkan. Setelah selesai, siswa dari lingkaran luar akan berputar searah jarum jam sedangkan siswa dari lingkaran dalam tetap di posisi semula. Sehingga semua siswa akan memiliki lawan bicara yang berbeda-beda dan mendapatkan topik pembicaraan yang berbeda pula. Demikian seterusnya.

\section{METODE PENELITIAN}

Penelitian ini menggunakan metode penelitian eksperimen kuasi atau semu, yaitu hanya menggunakan kelas eksperimen saja tanpa menggunakan kelas control. Desain penelitian yang digunakan dalam penelitian ini adalah penelitian eksperimen kuasi atau penelitian eksperimen semu atau pre-test and post-test one group. Sampel dalam penelitian ini adalah siswa kelas XII IPA 2 SMA Pasundan 2 Bandung yang terdiri dari 16 orang siswa. Teknik memilih sampel yang digunakan adalah probability sampling dengan teknik random sampling, yaitu teknik sampling yang digunakan oleh peneliti apabila populasi dari mana sampel diambil merupakan populasi homogen yang hanya mengandung satu ciri (Arikunto, 2010, hlm. 95).

Adapun teknik pengolahan data untuk menunjukkan hasil data tes dalam penelitian ini dengan menggunakan t-hitung, yaitu sebagai berikut:

1. Mengolah data pre-test dan post-test.

2. Mencari mean pre-test $(\mathrm{Mx})$.

3. Mencari mean post-test (My). 
4. Mencari gain (d) antara pre-test dan post-test.

5. Mencari mean gain (Md) antara pre-test dan post-test.

6. Mencari $t_{\text {hitung. }}$

7. Melakukan uji hipotesis yaitu dengan menguji kebenaran $t_{\text {hitung }}$ dengan membandingkannya dengan $\mathrm{t}_{\text {tabel }}$.

Untuk menganalisis data, instrumen yang digunakan dalam penelitian ini adalah tes dan angket. Tes dilakukan dua kali pre-test dan post-test. Angket diberikan kepada sampel untuk mengetahui pendapat siswa tentang pembelajaran bahasa Jepang terutama dalam aspek berbicara dengan menggunakan metode cooperative learning tipe inside-outside circle. Teknik pengolahan data angket adalah dengan cara menginterpretasikan jawaban dari hasil persentase setiap butir pertanyaan dalam angket. Jawaban dari angket dijumlahkan kemudian disusun frekuensinya. Frekuensi jawaban kemudian dimasukkan kedalam table frekuensi.

\section{HASIL DAN PEMBAHASAN}

Kegiatan penelitian ini dilaksanakan di SMA Pasundan 2 Bandung dan dilaksanakan dalam enam kali pertemuan. Penelitian ini dilakukan di kelas eksperimen yaitu kelas XII IPA 2 SMA Pasundan 2 Bandung tahun ajaran 20142015.

Pada pertemuan pertama, peneliti memberikan pre-test kepada kelas ekperimen untuk mengetahui kemampuan berbicara sampel sebelum diberikan treatment. Dari hasil pretest ini didapatkan hasil berupa nilai dalam bentuk angka sebagai data awal untuk proses analisis data selanjutnya. Dari data awal ini dapat disimpulkan rata-rata keterampilan berbicara pembelajar yang menjadi sampel penelitian adalah 60,312.

Setelah dilaksanakannya pretest, penelitian dilanjutkan dengan memberikan treatment pada empat kali pertemuan berikutnya. Pada setiap treatment, diterapkan metode cooperative learning tipe inside-outside circle dalam pembelajaran bahasa Jepang untuk meningkatkan kemampuan berbicara pembelajar.

Kemudian pada pertemuan terakhir, peneliti memberikan post-test dan angket kepada kelas eksperimen untuk mengetahui kemampuan berbicara sampel setelah diberikan treatment. Dari data hasil post-test ini dapat disimpulkan bahwa nilai rata-rata kemampuan berbicara pembelajar yang menjadi sampel penelitian adalah 70. Berdasarkan data pre-test dan post-test, terjadi kenaikan nilai rata-rata sampel dari kelas eksperimen setelah diberikannya treatment.

Berdasarkan analisis data dengan menggunakan perhitungan statistik diperoleh nilai t-hitung sebesar 4,205. Dengan demikian, t-hitung 4,205 > t-tabel 2,13 untuk 5\% dan t-hitung 4,205 > t-tabel 2,95 untuk 1\%. t-hitung > t-tabel yang berarti Hk diterima. Hal ini membuktikan bahwa ada perbedaan yang signifikan terhadap kemampuan berbicara bahasa Jepang siswa antara sebelum dan sesudah dilaksanakannya pembelajaran bahasa Jepang dengan metode cooperative learning tipe inside-outside circle.

Jika dilihat dari data hasil analisis angket yang telah diisi oleh setiap responden, maka dapat disimpulkan beberapa hal, yaitu lebih dari setengah responden memiliki minat belajar bahasa Jepang terutama dalam aspek berbicara. Lebih dari setengah responden $(62,5 \%)$ menyatakan bahwa kesempatan untuk berlatih berbicara bahasa Jepang kurang cukup. Dan setengah responden (50\%) 
menyatakan bahwa metode dan teknik pembelajaran bahasa Jepang yang dilaksanakan selama ini kurang memberikan kesempatan berbicara. Adapun dari hasil analisis angket tentang pendapat responden mengenai metode cooperative learning tipe inside-outside circle ini dapat disimpulkan beberapa hal sebagai berikut: setengah dari responden (50\%) menyatakan bahwa dengan metode cooperative learning tipe inside-outside circle ini, sangat memberikan kesempatan berbicara dalam bahasa Jepang. Selain itu, lebih dari setengah responden $(68,75 \%)$ menyatakan bahwa intensitas berlatih berbicara bahasa Jepang sangat berpengaruh terhadap kemampuan berbicara bahasa Jepang. Kemudian, lebih dari setengah responden $(56,25 \%)$ menyatakan bahwa metode cooperative learning tipe inside-outside circle ini sangat menarik untuk dilaksanakan dalam pembelajaran bahasa Jepang. Sementara itu, hampir setengah dari responden $(31,25 \%)$ menyatakan cukup mengalami kesulitan saat melaksanakan pembelajaran bahasa Jepang dengan metode cooperative learning tipe inside-outside circle. Sedangkan, lebih dari setengah responden $(68,75 \%)$ menyatakan tidak begitu mengalami kesulitan saat melaksanakan pembelajaran bahasa Jepang dengan metode cooperative learning tipe inside-outside circle. Sedangkan tidak seorangpun responden $(0 \%)$ yang menyatakan tidak mengalami kesulitan saat melaksanakan pembelajaran bahasa Jepang dengan metode cooperative learning tipe inside-outside circle. Berdasarkan hasil analisis dari angket terbuka, beberapa responden berpendapat bahwa metode ini menarik untuk diterapkan di pembelajaran bahasa Jepang. Dan ada responden yang merasakan mendapatkan kesempatan lebih untuk berbicara bahasa Jepang dengan di terapkannya metode cooperative learning tipe inside-outside circle dalam pembelajaran bahasa Jepang.

\section{KESIMPULAN}

Berdasarkan hasil penelitian yang telah dilaksanakan, dapat disimpulkan beberapa hal sebagai berikut:

1. Berdasarkan dengan hasil pre-test yang dilaksanakan sebelum diterapkannya metode cooperative learning tipe inside-outside circle dalam pembelajaran bahasa Jepang, menunjukkan kemampuan berbicara bahasa Jepang sampel penelitian masih kurang karena sampel masih mengalami kesulitan saat berbicara diantaranya karena sampel masih belum percaya diri untuk berbicara dalam bahasa Jepang. Sehingga membuat sampel hanya menggunakan kosakata seadanya, masih sering terbata-bata, tetapi cukup dapat memahami pertanyaanpertanyaan yang diberikan.

2. Setelah sampel diberikan treatment yaitu diterapkannya metode cooperative learning tipe inside-outside circle dalam pembelajaran bahasa Jepang sebanyak empat kali pertemuan, dilaksanakan post-test untuk melihat sejauh mana kemampuan berbicara bahasa Jepang siswa setelah diberikan treatment. Dari hasil post-test diketahui kemampuan berbicara bahasa Jepang siswa sudah cukup karena siswa sudah dapat menguasai banyak kosakata, cukup lancar saat berbicara karena sering berlatih berbicara ketika menggunakan metode cooperative learning tipe inside-outside circle, dan tingkat pemahaman sampel terhadap topik atau pertanyaan bahasa Jepang sudah cukup baik.

3. Hasil analisis pada kedua data tes ini secara statistik, dapat disimpulkan bahwa ada perbedaan yang signifikan. Dengan membandingkan nilai t-hitung dengan nilai t-tabel, didapatkan t-hitung > t-tabel yang berarti Hk diterima. Hal ini membuktikan bahwa ada perbedaan yang signifikan terhadap kemampuan 
berbicara bahasa Jepang siswa antara sebelum dan sesudah dilaksanakannya pembelajaran bahasa Jepang dengan metode cooperative learning tipe insideoutside circle.

4. Berdasarkan hasil analisis data angket yang diisi oleh responden dapat disimpulkan bahwa setengah dari responden menyatakan sangat mendapatkan kesempatan berbicara bahasa Jepang saat dilaksanakannya pembelajaran bahasa Jepang dengan metode cooperative learning tipe inside-outside circle. Kemudian, lebih dari setengah responden menyatakan bahwa intensitas berlatih berbicara mampu meningkatkan kemampuan berbicara bahasa Jepang. Selain itu, lebih dari setengah responden tidak begitu mengalami kesulitan saat penerapan metode cooperative learning tipe inside-outside circle pada pembelajaran bahasa Jepang. Kemudian, lebih dari setengah responden merasakan bahwa dengan diterapkannya metode cooperative learning tipe inside-outside circle dalam pembelajaran bahasa Jepang cukup memberikan pengaruh dalam kemampuan berbicara bahasa Jepang. Selanjutnya, lebih dari setengah responden menyatakan bahwa metode cooperative learning tipe inside-outside circle ini cukup menarik, dan lebih dari setengah responden cukup setuju bahwa metode cooperative learning tipe inside-outside circle mampu membantu meningkatkan kemampuan berbicara bahasa Jepang.

\section{REFERENSI}

Arikunto, S. (2010). Prosedur penelitian suatu pendekatan praktik. Jakarta: Rineka Cipta.

Isjoni. (2011). Cooperative learning: Efektivitas pembelajaran kelompok. Bandung: Alfabeta.

Lie, A. (2002). Cooperative learning. Jakarta: PT. Grasindo.

Ogawa, Y. (1982). Nihongo kyouiku jiten. Tokyo: Daiosamu Toshokan. 


\title{
学習者の話す能力に対する COOPERATIVE LEARNINGの
}

\section{INSIDE-OUTSIDE CIRCLEタイプの方式の効果}

$$
\text { ディアル ラーマ ディヤンティ }
$$

1002769

\begin{abstract}
要旨
アンケートの結果によると、半分の学習者は話す機会が上達することにな つたと答えた。話す能力を上達するために、よく練習しなければならない と思われる。しかし、学習者は日本語の授業中にも話す機会があまりなか ったと思われる。さらに、教師が面白くない指導をすれば、学習者の話す 動機を持たないと思われる。実際、現在に学習者は世界的にコミュニケー ションするため、外来語で話せるはずだと思われる。そこで、本研究には 日本語の話す能力の指導するため、Cooperative Learning の Inside-Outside Circle タイプの方式を試みたい。本研究の目的が Cooperative Learning の Inside-Outside Circle タイプの方式は学習者の日本語の話す能力に影響を知 りたい。Cooperative Learning の Inside-Outside Circle タイプの方式を使用す る前のテストと使用した後のテストと比べる。二つのテストから、学習者 の日本語の話す能力の違いを明らかにすることである。それに、 Cooperative Learning の Inside-Outside Circle タイプの方式に対して、学習者 の感想を知るためである。本研究で使用する方法は、Quasi Experiment とい う方法であり、One Group Pretest - Posttest Design を使用する。サンプルは 16 人で、バンドン第 2 パスンダン高校の三年生である。データの収集方 法としてはテストとアンケートを使用する。データを分析した結果、 db は 15 で、 $\mathrm{t}$ 得点は 4,205 で $\mathrm{t}$ 表は 2,13 と 2,95 である。つまり、 $\mathrm{t}$ 得点は $\mathrm{t}$ 表よ り高いことが分かる。いいかえれば、学習する前と学習した後の違いがあ るということが見られる。アンケートの結果によると、半分以上の学習者 は Cooperative Learning の Inside-Outside Circle タイプの方式が非常に面白い と答えたが、半分の学習者は話す機会が上達することになったと答えた。 半部以下の学習者は Cooperative Learning の Inside-Outside Circle タイプの方 式が難しいと感じていると答えたが、半分以上の学習者は Cooperative Learning の Inside-Outside Circle タイプの方式は日本語の話す能力に影響を 与えると答えた。
\end{abstract}

キーワード : 話す能力、Cooperative Learning の Inside-Outside Circle タイプの方式 
Diyanthi, Judiasri, Risda, The Effectivity of Cooperative Learning

\section{学習者の話す能力に対する COOPERATIVE LEARNINGの}

\section{INSIDE-OUTSIDE CIRCLE タイプの方式の効果}

1.はじめに

話す能力ということは話したいことを提供することができること である。しかし、外国語の学習者にとって、日本語で話す時、色々な問 題がある。一つの問題は日本語で話す機会があまりないと思われる。授 業中にも話す機会があまり十分ではない。さらに、教師が面白くない指 導をすれば、学習者の話す動機を持たないと思われる。そのため、その 問題を答えるために色々教え方を探すこともある。その一つは Cooperative Learning の Inside-Outside Circle タイプの方式を使用するこ とである。

Cooperative Learning というのは授業の中に学習者がチームワーク で勉強するということである。チームワークで勉強するから、授業中で 学習者は教師より色々な活動をする機会が多いと思われる。それに、 Cooperative Learning で色々な日本語能力がある学習者はお互いに助けら れると思う。例えば、いい日本語能力がある学習者はまだ良くない日本 語能力がある学習者に助けられる。

Cooperative Learning の Inside-Outside Circle タイプの方式で学習者 が日本語で話す機会が多いと思われる。Cooperative Learning の InsideOutside Circle タイプの方式で学習者が外部丸のグーループと奥丸のグル 一プを作って、外部丸のグーループは奥丸のグループと向かい合って、 別々の話題について話させた。

そこで、Cooperative Learning の Inside-Outside Circle タイプの方式 は日本語で話す能力を上達できるかどうかまだ分からないから、本研究 で調査するつもりである。

2 . 研究の問題

a. Cooperative Learning の Inside-Outside Circle タイプの方式を使う前、 学習者の日本語の話す能力はどうか。

b. Cooperative Learning の Inside-Outside Circle タイプの方式を使った後、 学習者の日本語の話す能力はどうか。

c. Cooperative Learning の Inside-Outside Circle タイプの方式を使う前と 使った後、学習者の話す能力に対する Cooperative Learning の Inside-Outside Circle タイプの方式の効果はどうか。

d. Cooperative Learning の Inside-Outside Circle タイプの方式に対する学 習者の感想が何か。 
3. 研究の目的

本研究の目的は問題の設定を答えるためである。次は本研究の目的 である。

a. Cooperative Learning の Inside-Outside Circle タイプの方式を使う前、学 習者の日本語の話す能力を明らかにするためである。

b. Cooperative Learning の Inside-Outside Circle タイプの方式を使った後、 学習者の日本語の話す能力を明らかにするためである。

c. Cooperative Learning の Inside-Outside Circle タイプの方式を使う前と使 った後、学習者の日本語の話す能力の違いがあるかどうかを明らかに するためである。

d. Cooperative Learning の Inside-Outside Circle タイプの方式に対する学習 者の感想を知るためである。

4. 研究の対象者及び方法

a. 対象者

本研究の対象者はバンドン第 2 パスンダン高校の三年生であ る。対象者は三年生の IPA 2 クラスで、1 6 人である。

b. 方法

本研究の方法は、Quasi Eksperiment という方法であり、One Group Pretest - Postest Design である。

本研究のデザインは次のようである。

\begin{tabular}{|c|c|c|}
\hline $0_{1}$ & $\mathrm{X}$ & $0_{2}$ \\
\hline
\end{tabular}

$0_{1}$ : Pre-test (Cooperative Learning の Inside-Outside Circle タイプの方式を 使う前のテスト)

$\mathrm{X}$ : 実験

$0_{2}$ : Post-test (Cooperative Learning の Inside-Outside Circle タイプの方式を 使った後のテスト)

5. 研究の用具

データの収集はテストとアンケートを使用する。テストは学習者の 日本語の話す能力を明らかにするためである。また、アンケートは Cooperative Learning の Inside-Outside Circle タイプの方式に対する学習者 の感想を知るためである。 
6. データの分析

a. テストのデータ分析の手段

1). Gain を計算する

Gain $=$ Postest - Pretest

2). Mean Gainの平均を計算する

$$
M d=\frac{\Sigma d}{N}
$$

Md : Pretest および Postest 相違の平均

$\mathrm{N}$ : 対象の数

3). $\Sigma x d^{2}$ を計算する

$\sum x d^{2}=\sum d^{2}-\frac{\left(\sum d\right)^{2}}{N}$

$\Sigma x d^{2}$ : 標準偏差と平均の相違

4). $\mathrm{t}$ 得点を計算する

$$
t_{\text {hitung }}=\frac{M d}{\sqrt{\frac{\sum x d^{2}}{N(N-1)}}}
$$

(Arikunto, 2010, hlm. 124).

b. アンケートの分析

$$
\mathrm{P}=\frac{f}{n} \times 100 \%
$$

データの解釈に用いられる手引は通りである

\begin{tabular}{|c|c|}
\hline $0 \%$ & いない \\
\hline $1 \%-5 \%$ & ほとんどいない \\
\hline $6 \%-25 \%$ & 一部いる \\
\hline $26 \%-49 \%$ & 半部以下 \\
\hline $50 \%$ & 半分 \\
\hline $51 \%-75 \%$ & 半分以上 \\
\hline $76 \%-95 \%$ & かなり多い \\
\hline $96 \%-99 \%$ & ほとんど全部 \\
\hline $100 \%$ & 全部 \\
\hline
\end{tabular}

(Sudjiono, 2001, hlm. 40-41)

本研究では 2014 年 9 月 17 日に Pretest を行った。それで、実験を四 回あげた。即ち、2014 年 9 月 19 日、2 4 日と 10 月 1 日、8 日に実施し た。2 014 年 10 月 10 日に Postest を行った。

a. テストの内容

1). Pretestは 2014 年 9 月 17 日に Pretestを行った。研究者は学習 者と問答させた。話すテーマは「別々のうちの様子」についてであ 
る。最初は研究者が学習者に一人一人を呼んで、質問を与え、学習 者はその質問を答えた。

2). 2014 年 9 月 19 日に第一の実験を行った。 2014 年 9 月 19 日に第一の実験を行った。テーマは「マリアさんの部屋」について である。話題は「あなたのうち」と「あなたの部屋」と「あなたの だいどころ」と「あなたのいま」が与えた。この実験で、最初研究 者は話題を与え、学習者はグループの中に、その話題をディスカッ ションさせた。それで、学習者は全部二グループを作って、ーグル ープは外部丸のグーループであるが、他のグループは奥丸のグルー プである。外部丸のグーループは奥丸のグループと向かい合って、 別々の話題について話させた。それで、外部丸のグーループは動い て、奥丸のグループはそのままに動かずに、学習者は他の相手を会 えた。それで、外部丸のグーループは奥丸のグループと向かい合っ て、別々の話題について話させた。第一の実験に外部丸のグールー プは四回に動いて、学習者は相手と四回に日本語で話させた。

3). 2014 年 9 月 24 日に第二の実験を行った。テーマは「朝何をし ますか」についてである。話題は「朝の活動」と「夜の活動」と

「日曜日の活動」と「土曜日の活動」が与えた。この実験で、実験 し方は前の実験と同じである。

4). 2014 年 10 月 1 日に第三の実験を行った。テーマは「何時にお きますか」についてである。話題は「朝、何をしますか。何時にお きますか」と「昼、何をしますか。何時に昼ご飯を食べますか」と 「夕方、何をしますか。何時にテレビを見ますか」と「夜、何をし ますか。何時に寝ますか」が与えた。この実験で、実験し方は前の 実験と同じである。

5). 2014 年 10 月 8 日に第四の実験を行った。テーマは「朝ご飯」 についてである。話題は「朝ご飯」と「昼ご飯」と「昨日の晚ご飯」 と「昨日の昼ご飯」が与えた。この実験で、実験し方は前の実験と 同じである。

6). Post-test は 2014 年 10 月 10 日に Post-test を行った。研究者は 学習者と問答させた。話すテーマは別々の毎日の活動について、話 題は「何時に〜ますか」と「何をしますか」と「何を食べますか」 がある。最初は研究者が学習者に一人一人を呼んで、質問を与え、 学習者はその質問を答えた。

テストの行う目的は Cooperative Learning の Inside-Outside Circle タ イプの方式を使う前と使った後に、テストは学習者の日本語の話す 能力はどこまであるのかを明らかにするためである。

b. アンケート

アンケートは Postest を終わった後に実施した。アンケートの目的は学 習者の感想を知るためである。アンケートの内容は Cooperative Learning の Inside-Outside Circle タイプの方式に関する選択式の質問が 1 1つであり、エッセイの質問が一つである。 
7. 結果及び解釈

\begin{tabular}{|c|c|c|}
\hline & 実験前 & 実験後 \\
\hline 平均点 & 60,312 & 70 \\
\hline $\mathrm{t}$ 得点 & \multicolumn{2}{|c|}{4,205} \\
\hline
\end{tabular}

テストの結果によると、トリートメントを与えられる前、学習者 の平均点数は 60,312 点である。四回のトリートメントを与えた後、学習 者の平均点数は 70 点である。データの計算結果から db は 15 で、 $\mathrm{t}$ 得点 は 4,205 で $\mathrm{t}$ 表 $5 \%$ は 2,13 と $1 \%$ は 2,95 示している。つまり $\mathrm{t}$ 得点は $\mathrm{t}$ 表 より高いということが分かる。 $H_{0}$ (ゼロかせつ）は拒否された。いわば、 Cooperative Learning の Inside-Outside Circle タイプの方式使用した後、有 意義な成果が見られる。

アンケートの結果によると、半分 $(50 \%)$ の学習者は Cooperative Learning の Inside-Outside Circle タイプの方式が日本語の話寸機会をよく 上達することができると答えた。それから、半分以上 $(56,25 \%)$ の学習 者は Cooperative Learning の Inside-Outside Circle タイプの方式が非常に 面白いと答えた。半部以下 $(31,25 \%)$ 学習者は Cooperative Learning の Inside-Outside Circle タイプの方式が難しいと感じていると答えたが、半 分以上 $(68,75 \%)$ 学習者は Cooperative Learning の Inside-Outside Circle タイプの方式は日本語の話寸能力に影響を与えると答えた。

8.終わりに

a. 結論

データ分析の結果によると、本研究の結論は次のように述べている。

1). テストの結果によると、トリートメントを与えられる前、学習者の平 均点数は 60,312 点である。

2). 四回のトリートメントを与えた後、学習者の平均点数は 70 点である。

3). テストによると、Cooperative Learning の Inside-Outside Circle タイプの

方式を使用した後、学習者の日本語の話寸能力に有意義な成果がある。 これは $\mathrm{t}$ 得点 $=4,205>\mathrm{t}$ 表 $5 \% 2,13 、 \mathrm{t}$ 表 $1 \% 2,95 （ \mathrm{db}=15 ）$ 示される。

4). アンケートの結果によると、半分以上の学習者は Cooperative Learning

のInside-Outside Circle タイプの方式が非常に面白いと答えたが、半分 の学習者は話す機会が上達することになったと答えた。半部以下の学 習者は Cooperative Learning の Inside-Outside Circle タイプの方式が難 しいと感じていると答えたが、半分以上の学習者は Cooperative Learning の Inside-Outside Circle タイプの方式は日本語の話寸能力に影 響を与えると答えた。

b. 提案

日本語の教師のための、学習者の話す能力を上達できて、学習者 を動機付けするために、Cooperative Learning の Inside-Outside Circle タ 
JAPANEDU, Vol. 1, No. 1, Juni 2016

イプの方式を日本語の授業中に使用することを検討させることが可能 である。

他の研究者のための、他の授業に Cooperative Learning の InsideOutside Circle タイプの方式を膨らさせることが可能である。

\section{選考文献}

Arikunto, S. (2010). Prosedur penelitian suatu pendekatan praktik. Jakarta: Rineka Cipta.

Sudjiono, A. (2001). Pengantar evaluasi pendidikan. Jakarta: Raja Grafindo Persada. 